\title{
World university rankings: Reflections on teaching and learning as the Cinderella function in the South African higher education system
}

Author:

Ms Raazia Moosa ${ }^{1}$

Affiliation:

${ }^{1}$ University of the

Witwatersrand

Correspondence to:

Ms Raazia Moosa,

Head: Academic

Support, Centre for

Learning, Teaching and

Development,

University of the

Witwatersrand,

Johannesburg

Private Bag 3,

Wits 2050,

South Africa

Tel:

+27117171442

E-mail:

raazia.moosa@wits.ac.za

DOI:

$10.15249 / 12-1-165$

\section{Keywords:}

world university rankings; ranking methodology, teaching and learning; higher education; South Africa

\section{Abstract}

Not much has been devoted to teaching and learning in the world university ranking debate. This theoretical article is based on a qualitative research approach with a case study research design guiding the literature review on global ranking systems. The findings indicate that in the South African context, ethical decision-making should guide decisions regarding whether a university should be ranked. As market leaders, global rankings have the potential to set new trends in rankings that focus on teaching and learning as essential functions of a university on par with research. In addition, the importance accorded to global rankings should not be considered for a few universities but for the value they add to the entire South African higher education (HE) system.

\section{Introduction}

Within universities, a tension exists between research and teaching and learning, where research is often accorded a higher status, creating a Cinderella effect by rendering teaching and learning of lesser importance. World university rankings, also referred to as global rankings, are contentious although they have become a permanent feature of the HE system internationally (Rauhvargers, 2013; Swail, 2011; Altbach et al., 2009; Marginson, 2007b). Lindsay (2013) argues that institutions have emphasised the importance of publications and prestige, which contribute to national and institutional reputation. Publications increase rankings, thereby contributing to the lower prestige given to excellent teachers as compared to excellent researchers. This has consequently led to a decline in the attention given to teaching. Pressure exists in the HE 
system to play the ranking game without acknowledging that there are expertise and pockets of teaching excellence in universities. Through their performance criteria, global rankings are transforming universities into becoming similar and conforming to a single hierarchy (Marginson, 2007a). In order to compete in the global HE market and improve their rankings, some universities have adopted a business model to mitigate the effects of globalisation and have begun to view themselves and HE as a business. Corporate universities have emerged as a result of neoliberalism and enforced the commercialisation and marketisation of HE (Giroux, 2009; Giroux, 2002). Global ranking systems are an example of the commercialisation and marketisation of HE and thus have the agency either to perpetuate teaching and learning as the Cinderella function in HE, through the ranking game, or to holistically focus their performance criteria on all the core functions of universities. Ethical policy decision-making in $\mathrm{HE}$ is thus essential.

Global rankings have been at the centre of debate in the global HE arena (IHEP, 2009). Previous research focused on how reputational rankings affect organisations (O'Connell, 2015; Altbach et al., 2009; Martins, 2005), methodological limitations and the purpose, statistics and validity of rankings (Goglio, 2016; Soh, 2016; Mohamedbhai, 2015; Enders, 2014; Gonzales \& Nunez, 2014; Rauhvargers, 2013; Marginson, 2008). O’Connell (2015) argues that the majority of the literature on global rankings focuses on the effects at institutional and national level. What is not well understood is the importance given to teaching and learning in rankings as only a few international studies have focused on this (Swail, 2011; Kuh, 2011; Lane, 2011). Except for a few studies on global rankings in South Africa with relevance to this article (Dlamini, 2016; Ntshoe \& Selesho, 2014; Badat, 2010a), not much attention at a systemic level has been devoted to the importance of teaching and learning in global rankings.

This theoretical article reviews relevant literature in the public domain on global rankings with particular reference to teaching and learning in the ranking performance criteria. This is accomplished by discussing the three global rankings: the Academic Ranking of World Universities (ARWU), Times Higher Education (THE) and Quacqarelli-Symonds Rankings (QS) and their limitations. Commercialisation and marketisation of $\mathrm{HE}$ is then addressed to provide a context for $\mathrm{HE}$ and the emergence of global ranking systems. I then highlight responses to global rankings before discussing global rankings and their social impact. Following this, I present the methodology for this study, before analysing global rankings in the South African context and how global rankings impact on different types of South African universities. This article concludes with insights for policy makers and university leaders to move towards ethical decision-making while playing the ranking game.

\section{World university ranking systems and their limitations}

Altbach (2012) argues that rankings are a consequence of massification, competition and the commercialisation of $\mathrm{HE}$, and contribute to the complexity of HE. Consensus is reached in the literature that rankings are not likely to disappear (Rauhvargers, 2013; 
Swail, 2011; Handel \& Stolz, 2008). The purpose of a ranking system depends on who the intended user is and which organisation is doing the ranking. Higher education institutions are thus developing strategies to increase their international scope by developing world-class universities that are ranked, even though the concept of 'worldclass' is ill defined (Hazelkorn, 2014) and no consensus exists on how it is measured or benchmarked (Handel \& Stolz, 2008).

The focus of this article is on the ARWU, also known as the Shanghai Ranking, the THE and QS ranking systems. Rauhvargers (2013) describes the ARWU as the most consolidated of the popular global ranking systems. The THE only ranks universities that teach undergraduates and has 13 detailed performance indicators. The THE claims to assist students and their families with choosing where to study based on the five areas which include citations; teaching (the learning environment); research (volume, income); international outlook; and industry income (knowledge transfer) (THE Website, 2016).

The QS global ranking system is administered by a global, career and education company that specialises in the area of education and study abroad (Mohamedbhai, 2015). The QS ranking claims to "help students make informed comparisons of leading universities around the world" (QS Website, 2016). It consists of six performance indicators, with four criteria: research, teaching, employability and internationalisation. The QS classification thus seeks to enable universities to view their ranking in terms of size, subject range, research intensity and age.

Methodological limitations of global rankings have been noted in the extant literature by Dlamini (2016), Goglio (2016), Enders (2014), Ntshoe and Selesho (2014), Lane (2011), and Marginson and Van der Wende (2007), and indicate that ranking systems are not entirely transparent (Lane, 2011). The three global ranking systems (ARWU, THE, QS) summatively rank universities hierarchically based on the assumption that a university's characteristics can be reduced to a single number that can be compared to another university. These three examples of whole university rankings use proxies or arbitrary measures to construct composite indexes to measure quality or performance (Ntshoe \& Selesho, 2014; Marginson, 2007b). According to Marginson (2007b) whole-institutional rankings norm one institutional type - a research-intensive university. The purpose, of $\mathrm{HE}$ in the ARWU is scientific research, which ignores other purposes such as teaching and community service, or problem solving (Marginson, 2007b). The ARWU thus norms a comprehensive research-intensive university with a scientific focus based on the Anglo-American system (Marginson, 2007b). The ARWU is not holistic, but uses reliable data that is available internationally for comparison to measure research performance (Marginson, 2007b). The methodology is nevertheless regarded as being a sound basis for comparison globally since the criteria overwhelmingly focus on research as the core function of a university, which gives it more credibility in the academic community than student surveys or staff-student ratios (Altbach et al., 2009; Mohrman, Ma \& Baker, 2008). However, the quality of education criteria is biased towards alumni who have won Nobel prizes. Although the quality of education indicator weighs $10 \%$, it is not sufficient 
to measure teaching and learning, or the quality of teaching and learning. As such, the ARWU criteria and performance indicators do not have a teaching and learning focus.

A similarity between the THE and QS is that they focus on undergraduate education and exclude universities that do not teach undergraduates (Rauhvargers, 2013). The ARWU coverage of universities is limited to 500 universities, the THE ranks the top 100 universities and QS ranks the top 700. However, university rankings remain the focus and the benchmark (Goglio, 2016) and in this manner, the coverage of universities in rankings is limited rather than being global. They can thus not provide a global view of all universities.

According to Goglio (2016) some of the criteria in the THE do not add to the overall ranking score. The THE is thus less "transparent" (Marginson, 2007c:4) in its methodology but efforts are being made to change this. More recently the THE incorporated rankings of BRICS countries (Brazil, Russia, India, China and South Africa). The same 13 performance indicators are used in the BRICS and emerging economies rankings, although the weightings are recalibrated to reflect the specific characteristics of emerging economies (THE Website, 2016). In 2015, the THE announced an experimental ranking of 30 African universities based on citations of research articles in Elsevier's Scopus database (Mohamedbhai, 2015). However, the THE's focus is on reputation and international marketing, as opposed to teaching or research (Marginson, 2007c). A category exists for teaching, which is weighted $30 \%$ and focuses on the learning environment. Although the THE includes the learning environment, the performance indicators are proxies and do not directly address learning by focusing on the outcomes achieved by graduates. The quality of teaching is also not measured through standards for excellent teaching as performance indicators.

Teaching and learning quality is not adequately covered in the staff-student ratio (Marginson, 2007a) since the QS ranking only has one indicator (faculty-student ratio) that deals with teaching quality and assigns it $20 \%$. This indicator is a proxy for teaching quality and is intended to identify the universities that have small class sizes. The assumption is that low student-staff ratios foster better learning environments and that students in small classes benefit more from the teaching and learning experience than those in large classes. The reality, nevertheless, is that large classes are prevalent due to massification especially in developing countries making this proxy a crude measure of teaching quality (Rauhvargers, 2013) and insufficient for measuring teaching and learning within a university. However, Swail (2011) claims that we cannot measure institutional quality without measuring teaching and learning.

The audience of the THE and ARWU are universities since the criteria stem from academia (Gonzales \& Nunez, 2014). Despite conversations with academia, no theoretical or empirical justification exists for any of the measures or weightings. The proxies for teaching quality are based on the assumption that there is a correlation between the quality of research and the quality of teaching which is problematic (Goglio, 2016; Dill \& Soo, 2005a). Empirical research “... suggests that the correlation between research productivity and undergraduate instruction is very small and teaching and learning and 
research appear to be more or less independent activities" (Dill \& Soo, 2005a:507). Why the teaching proxy is weighted $30 \%$ in the THE and $20 \%$ in QS, is not clear in either of the ranking systems. Weights are arbitrarily assigned according to Buela-Casal et al. (2007) and there is thus no justification for any of the measures or the accompanying weightings (Marginson, 2007c).

Most rankings use input data rather than process or output data (Kuh, 2011; Swail, 2011). Student performance and learning indicators as measures of learning outcomes are not included in the three global rankings and there is "no indicator on the absolute quality of how teachers teach and how students learn" (Swail, 2011:33). According to Dill and Soo (2005b), information on learning processes and outcomes does not feature in most of the rankings such as the ARWU, THE and QS that alludes to measuring teaching quality. A strong research orientation has a negative correlation with factors related to teaching such as hours spent teaching and consulting,"commitment to student development, use of active learning techniques in the classroom and percentage of faculty engaged in teaching general education courses" (Marginson, 2007a). Output measures in the three global rankings are also limited and do not include knowledge, skills, abilities and values acquired by graduates.

Teaching and learning are complex processes and require more substantive coverage in the three global ranking systems. There is a paucity of research on the status and role of teaching and learning in HE globally (Altbach et al., 2009). Teaching and research are important functions but have not received the same level of attention or prestige in universities or in the three global ranking systems. Biggs and Tang (2011) argue that teaching and research should be viewed as equal. There is thus room for both competition and co-operation between the teaching and learning and the research functions in universities. However, the teaching function is essential to produce graduates for the knowledge economy who are skilled and adaptable. Postgraduate education may be a way for teaching to benefit from research and vice versa (Altbach et al., 2009). The tension between the core functions of a university - teaching and learning, research and community engagement - deserves careful consideration since these functions are poorly integrated (Altbach et al., 2009). Altbach et al. (2009) thus maintain that the challenge exists to accommodate both the teaching and learning and the research functions in the HE system. Altbach (2006:2) also argues that, "there are, in fact, no widely accepted methods for measuring teaching quality" and as such, no indicator exists on the quality of how teachers teach and how students learn (Swail, 2011). Rauhvargers (2013) thus argues that, "the limitations of rankings remain most apparent in efforts to measure teaching performance" (p. 26). This is evident in the performance criteria of the three ranking systems.

International reputation and research are strongly weighted in the three global rankings. Peer and professional surveys are used to gauge the reputation of a university based on subjective data (Swail, 2011). Rauhvargers (2013) argues that although reputation is paramount in the rankings, reputation surveys do not hold much value because reputation is substantial for the first few ranked universities but diminishes in significance 
thereafter. Dill and Soo (2005a) highlight that reputation via surveys is problematic due to the sampling method that is used. The respondents who are part of the sample cannot provide an evaluation of all the programmes offered in all fields; at most, they are able to focus on their discipline (Rauhvargers, 2013). Marginson (2007c) notes that a third of respondents to reputational surveys know about institutions other than their own. Rauhvargers (2013) thus highlights that "the practical implication of this approach is that if none of those surveyed consider a university among the top 30 in their field, the university will not be considered at all" (p.17). In addition, no information is available on what questions were asked in the reputation surveys (Rauhvargers, 2013). The THE has an indicator and the QS is widening its subject rankings, in which reputation remains paramount. Reputational surveys are thus used to a greater extent in QS than in THE and do not appear in ARWU (Altbach, 2012). Reputation is over-emphasised (Kuh, 2011) and this over-reliance on reputation surveys in the THE and QS makes them less credible. Altbach (2012) thus contends that expert advice is not a sound measure upon which to base rankings. The assumption that there is a correlation between reputation and teaching and learning is also flawed and assumes that students only value the university's reputation and not what they will learn or how what they learn, or will be taught (Marginson, 2007a). The reputational surveys are thus not adequate measures of learning or teaching quality and they are also not regarded as credible measures (Rauhvargers, 2013; Altbach, 2012; Dill \& Soo, 2005b; Marginson, 2007a, 2007b).

Internationalisation is addressed in the THE and QS as core criteria. Handel and Stolz (2008) argue that internationalisation is a good measure because it addresses the quality of HE institutions on a cross-national level to create a world-class university. The focus in global rankings on international staff and students is based on the assumption that international staff will make the university a better place to promote learning and that international students "will improve the outcomes achieved by students" (Swail, 2011:32). However, evidence to support these assumptions is lacking. Internationalisation also does not necessarily reflect the quality of student demands or the quality of a university's programmes and services. Policies are instituted in Asian universities in Hong Kong and Singapore, for example, that encourage the employment of research-active international staff (Altbach, 2012). According to Altbach (2012), staff are consequently recruited for their research and not for their teaching abilities. The value-add of internationalisation to the learning experiences of students and teaching quality is thus inadequately addressed in the internationalisation criteria. Internationalisation is also a consequence of the commercialisation and marketisation of HE to which I now turn.

\section{Commercialisation and marketisation of higher education}

Market forces have reshaped HE and positioned universities as corporate entities and students as customers (Giroux, 2009). The purpose of HE has been reformulated by neoliberalism (Giroux, 2002) and as such, neoliberalism has ushered in the 
commercialisation and marketisation of $\mathrm{HE}$. This has led to the corporatisation of universities and enhanced competition to the detriment of programmes which are geared towards critical social understandings (Monzó, 2014). The corporate university views the "university as a business, which increasingly views students as consumers, the classroom as a market place, and the public space of the university as an investment opportunity (Giroux, 2002:454). The commodification of knowledge and corporate interests is making inroads into HE according to Giroux (2009). As a result, scientific knowledge has been commodified. Monzó (2014) argues that the corporatisation of universities should be avoided since it is a consequence of neoliberal trends to commodify knowledge. The commodification and marketisation of HE has enabled universities to sell their teaching and research services to students and investors as products under the auspices of "knowledge capitalism" (Monzó, 2014:80). Neoliberalism has also led North American, Latin American, Asian and European countries to view HE as a private market good with students as consumers and faculty as labourers (Gonzales \& Nunez, 2014; Giroux, 2009; Giroux, 2002). Education as a commodity has also enabled universities to increase student fees whereas public education should be for the public good and not for profit. Students are thus bearing the brunt of the corporatisation and commodification of HE (Habib, 2016; Monzó, 2014). Competition for students thus takes place in the free market knowledge-based economy (Pinheiro, 2013) and Rossi (2010) argues that competition between universities for students and resources has also increased. However, the competition for students is based on reputation from ranking systems, which is a result of research rather than the quality of teaching and learning. Monzó (2014) contends that Western knowledge underpinned by masculine knowledge systems is valued in universities together with market-driven demands for programmes. Competition in the global context involves comparisons and benchmarks between world-class universities (Buela-Casal et al., 2007). Benchmarks are obtained from commercial companies who commercialise HE by ranking institutions and creating competition between universities. As such, global competition is also intensified by the ARWU's measure for the best researchers and international students. Bradmore and Smyrnios (2009) thus argue that intensive exposure to global markets fosters competitive risks, which are a result of globalisation.

\section{Responses to global rankings}

Reputational rankings such as the ARWU, THE and QS are an important source of institutional isomorphism (Martins, 2005). Isomorphism in rankings occurs as a result of the definition of an ideal university which is espoused in ranking systems. The pursuit of reputational excellence has led Enders (2014) to argue that rankings create a role model for what a world-class university standard should be in terms of criteria and outcomes. As such, universities with a focus on regional and national development, non-scientific fields of research and undergraduate teaching would not be highly ranked. Marginson (2007a) argues that rankings are transforming universities into becoming similar and consequently conforming to a single hierarchy. It is thus not surprising that hierarchical 
rankings created by global rankings cause lower-ranked universities to mimic those that are highly ranked, leading to homogenisation. As such, ranking systems create competition and convergence on strategies that appear to increase ranking positions (Marginson, 2008). Universities aspiring to be ranked assess how others improved their rankings and how they can imitate and mimic others and become more like them, which leads to organisational isomorphism (Goglio, 2016). Enders (2014:168) thus argues that rankings "fuel organisational isomorphism" because universities respond by changing their missions to imitate research universities that are highly ranked. The implication of isomorphism for teaching and learning is that the mimicking of highly ranked universities could steer universities towards a focus on research, postgraduate education, scientific programmes and, inadvertently, away from a focus on improving teaching and learning, thereby, maintaining teaching and learning as the Cinderella function in $\mathrm{HE}$ due to the focus on research in the global ranking criteria. Non-research universities may also morph into research-intensive universities by altering their missions to increase their ranking positions. This is problematic since isomorphism creates competition amongst and within universities as they pursue the same goal, which mitigates against some governments' policies to create a differentiated HE system (DHET, 2014; Altbach et al., 2009).

Global rankings such as the ARWU favour research performance, which increases mimicking the behaviour of highly ranked universities and thus steering universities away from diversity. Rossi (2010) argues that although little agreement exists on the form diversity should take, there is a tendency for universities to differentiate to deal with the demands placed on them. Competition for reputation could mitigate against policies that stimulate knowledge and a diversified HE system (Altbach et al., 2009). At a policy level, a drive to greater responsiveness to the needs of the knowledge society would be preferable (DHET, 2014). Differentiation thus represents a policy imperative that mitigates against isomorphism and provides universities with opportunities to develop niche areas to create a HE system that is differentiated to meet national, regional, cultural, social and economic development needs (DHET, 2014). The implication of differentiation for teaching and learning is that it opens up possibilities for teaching and vocationally oriented universities, and accommodates vertically, horizontally and diagonally differentiated universities. Diagonal differentiation within universities would allow faculty, departmental and disciple differentiation, which focuses less on what would improve rankings and instead accommodates differences in programmes and possibly over time improves the status of teaching and learning away from being the Cinderella function in HE. While isomorphism is characterised by homogenisation and low levels of diversity, differentiation is characterised by high levels of diversity. Global rankings have thus influenced both isomorphic and polymorphic policies in universities. Pressure exists for both diversification and homogenisation (Rossi, 2010). I thus argue that differentiation and isomorphism are two sides of the same coin when playing the global ranking game in $\mathrm{HE}$. 


\section{Global rankings and their social impact}

Rankings have made an impact on both policy and universities, and Goglio (2016) argues that national HE systems are all affected by rankings. At the national level, highly ranked universities are viewed as symbols of prestige and engines of the knowledge economy. Consequently, nations derive prestige from the number of universities that are ranked and have an interest in seeing their universities progress on the reputational ranking ladder (Marginson, 2007b). Governments have also linked a good economy to a good HE system (Swail, 2011), and Marginson (2007b:136) thus argues that rankings have "public and policy credibility". Rankings are also able to influence national and university policy and maintain credibility.

Changes to national education, funding, immigration and partnership policies have resulted from global rankings. In some countries, such as China and Japan, changes to national policy have included directives to move their universities up the ARWU ranking ladder (Swail, 2011; Altbach et al., 2009). Some countries, such as Vietnam and Chile, have committed to being amongst the world's top universities (IHEP, 2009; Marginson, 2008) and other countries such as the United Arab Emirates, India, Saudi Arabia and South Korea intend to use rankings to spur economic and international competition. According to Altbach et al. (2009), Brazil, Germany and other countries use rankings to allocate funding to HE institutions. Rankings are thus able to influence investment in particular programmes. Badat (2010a) argues that rankings have influenced the policy decisions made by governments, business and donors with regard to investment of funds, endowments and the award of research contracts. Lane (2011) further argues that funding agencies and foundations use rankings to allocate grants and that Japan, Taiwan, Singapore and Malaysia have used ranking strategically to improve their global competitive stance as well as their level of internationalisation and research output, which are favourably weighted in rankings (Lane, 2011). Rauhvargers (2013) also notes that in Denmark and the Netherlands, rankings have led to changes to immigration policies for migrants, which include the ranking position of the university where the applicant graduated.

Global rankings underpin policy-making and policy partnerships have also been influenced by rankings. National policies have been adapted to allow prestigious foreign universities to establish campuses in foreign countries in order to expand access to local students (Rauhvargers, 2013). Partnerships geared towards capacity building with former colonies in Africa and Latin America have been the focus of foreign policies in Europe (Altbach et al., 2009). Altbach et al. (2009) argue that in some countries, the choice of partner institutions, mergers of some universities as well as the recognition of foreign qualifications are influenced by rankings. Rauhvargers (2013) thus contends that global rankings have resulted in policies geared to the recognition of qualifications in the Russian Federation which only recognise foreign qualifications awarded by the first 300 positions of the ARWU, THE and QS rankings. Additionally, Brazil instituted a scholarship programme in 2011 to allow 100000 Brazilian students to study abroad and India concluded bilateral programme agreements in 2012 with the global top 500 foreign 
universities based on the THE and ARWU rankings (Rauhvargers, 2013). Such policies are unsound and raise ethical issues since rankings are based on research, not teaching or learning performance. While Gonzales and Nunez (2014) contend that rankings can be used for the development of national educational policy, the implication of agreements based on rankings is that good teaching-oriented universities or those who focus on the arts and humanities would not be eligible to enter into such partnerships due to either a low ranking or not being ranked at all.

Higher education rankings also affect institutional design and behaviour (Goglio, 2016; Marginson, 2007a). Goglio (2016) argues that rankings as a global phenomenon affect those universities that are ranked and want to improve their rankings as well as those that are not ranked, but aspire to be ranked. Marginson, and Van der Wende (2007) argue that those who have learned how to play the game have reshaped their priorities according to what would be most advantageous in terms of the rankings. Policies have thus been designed to optimise a university's position in global rankings (Marginson, 2007b). In order to increase their global rankings, universities that did not have prizewinners, strategised and invited distinguished scholars as visiting professors (Rauhvargers, 2013). Universities have also used data collected for ranking purposes as the basis of their strategic planning (Rauhvargers, 2013). As a response to global ranking imperatives, missions are being developed to include recruitment of international students, staff student exchange programmes, collaborative partnerships in research and curriculum reform (Maringe, 2010). Peters (2007) thus argues that challenging ranking criteria is impossible. However, universities are able to renegotiate the terms of the competition (Goglio, 2016) and a success has been that African universities have been able to renegotiate with the THE (Mohamedbhai, 2015).

Participation in global ranking systems has created policy opportunities and challenges for universities that have chosen to play the rankings game. In practice, a university's ranking is associated with being a world-class university and universities consequently use rankings to raise their international profile. Through coercive isomorphic processes, rankings have forced universities to improve their comparative position (Marginson \& Van der Wende, 2006). According to Gonzales and Nunez (2014) rankings convey the hierarchical organisation of $\mathrm{HE}$ and universities use them for accountability and to measure progress towards becoming world-class universities. Lane (2011) thus argues that these activities do not necessarily improve student outcomes or learning. However, rankings have influenced some universities to improve the quality of their academic programmes through a focus on new programmes, curriculum review and new teaching and learning practices (IHEP, 2009). At a policy level, universities have placed emphasis on rankings and Marginson (2007a) argues that a decline in the position of a university creates challenges for universities. Another challenge experienced is that those that are not ranked experience difficulty in a competitive international student market. In addition, a management challenge to universities results from the need to interpret the ranking results internally and externally. I now turn to the methodology for this study. 
This theoretical article is based on a qualitative research approach. A case study research design guided the literature review on global ranking systems in the public domain. The research problem explored is that not much has been devoted to teaching and learning in the global university ranking debate although core functions of universities include research as well as teaching and learning with the aspect of community/civic engagement embedded in both functions. The purpose of this article is to advance an understanding of how teaching and learning are incorporated into the global ranking methodologies and how this could lead to a more inclusive ranking regime. The central research question is: to what extent (if any) could rankings, through their focus on research, reinforce teaching and learning as the Cinderella function in the South African HE system.

A purposive sampling method was used of three ranking systems (ARWU, THE, QS) since these are the most well-known global ranking systems (Gonzales \& Nunez, 2014; Badat, 2010a; Altbach et al., 2009; IHEP, 2009). The ARWU and THE are also referred to as the "current leading rankings" which enjoy "high credibility and wide application" (Goglio, 2016:213). The analysis assumes that if South African universities meet the criteria to be ranked, then they are able to play the global ranking game. The limitation of this article is that the analysis is limited to the 2015/16 rankings of universities in these three global ranking systems. Caution should thus be applied in extrapolating to other ranking systems. I now turn to the South African context and how rankings may impact on differentiation and what the possible effects of rankings are on different types of universities as well as teaching and learning in the South African HE system.

\section{Global rankings and the South African context}

South African HE institutions were reconfigured to reflect a differentiated HE system in 2005 (Badat, 2010b; DoE, 1997). The South African HE landscape is consequently characterised by a single, co-ordinated and differentiated HE system which comprises: universities, universities of technology, comprehensive universities, contact and distance universities and various colleges (Badat, 2010b). Differentiation is evident in institutional types, missions, programmes, size and knowledge-production, which was an explicit outcome of the National Plan for HE (DoE, 1997) in order to address previous inequalities and inefficiencies in the South African HE system. The HE system comprises $26 \mathrm{HE}$ institutions of which 11 are universities, 6 are comprehensive universities and 6 are universities of technology. Three new universities were recently established to offer programmes in provinces where there were no universities. Universities in South Africa are thus not homogenous although no methodology exists on how to successfully implement differentiation (Cloete, 2014).

In the South African differentiated system, universities would typically offer universitytype programmes, while comprehensive universities could offer both university-type and technikon-type programmes with teaching and applied research as their focus. Universities of technology would offer programmes in technology and focus on teaching 
and strategic and applied research in professional practice and technology (Ntshoe \& Selesho, 2014). These three institutional types can further be categorised into historically advantaged and disadvantaged institutions. Historically advantaged universities were equipped with funding, infrastructure and qualified staff, which allowed them to offer programmes in science, engineering and health sciences (Ntshoe \& Selesho, 2014). Historically advantaged universities consequently retain advantages from the past and are thus able to play the global ranking game.

Ntshoe and Selesho (2014) classified South African universities into Category A, top research-intensive universities; Category $B$, teaching and research universities; and Category $\mathrm{C}$, teaching universities with limited research. This classification is based on the percentage of National Research Fund (NRF)-rated academics and researchers at the various universities. Ntshoe and Selesho (2014) also highlight that research-intensive and comprehensive universities allocate a moderate percentage of expenditure to teaching whereas universities of technology allocate a high percentage of their expenditure to teaching. The three categories of universities (see Table 1) are consistent with Cloete's (2014) analysis of knowledge-producing universities in South Africa. Cloete (2014) placed historically advantaged universities such as University of Cape Town, University of the Witwatersrand, Stellenbosch University and Rhodes University in a high knowledgeproducing category. The majority of the other universities are categorised as medium knowledge-producing universities while the universities of technology are categorised as low knowledge-producing universities. Using the U-Map indicators, Ntshoe and Selesho (2014) indicate that research-intensive universities are thus able to compete in global rankings whereas comprehensive universities have limited capacity and universities of technology have even less capacity to play the global ranking game. However, Cloete (2014) further notes that the Universities of the Western Cape and Fort Hare are increasing their research output, which will improve their ability to compete in global rankings. Table 1 thus gives a relatively good representation of research-intensive and teachingoriented universities as well as the ability of universities to meet the performance criteria of global ranking systems.

Ntshoe and Selesho (2014) argue that the reputation race has begun, which is fostering homogenisation and the imitation of those universities that have been able to successfully play the ranking game. Normative and coercive processes inherent in global rankings, such as a reputation in science and research, have resulted in the neglect of other purposes of HE such as teaching and learning. Although global forces may be driving South African universities towards isomorphism in the ranking game, differentiation is being pursued by the government to create a diverse HE landscape. Although no theory exists to explain the conditions under which differentiation takes place in HE (Rossi, 2010), little agreement exists on the form diversity should take since a recognition exists that diversity has many dimensions that could lead to diversity in one university and homogeneity in another (Rossi, 2010). However, differentiation in South Africa represents a policy imperative that mitigates against isomorphism and creates a HE system that is differentiated (DHET, 2014). 
The desire to have a world-class university is dependent on the resources of both the country and a university (Altbach et al., 2009). Some governments, such as those in China, allocate resources to improve rankings, thus creating inequality in their HE systems (O'Connell, 2015). The South African government is unable to allocate resources to the historically advantaged research universities, such as the University of Cape Town and the University of the Witwatersrand, to improve their positions in global ranking systems. This would inevitably be at the expense of historically disadvantaged universities such as the University of Limpopo and the University Venda, which are not ranked in the ARWU, THE and QS global ranking systems. However, diversity has been integral to placing some universities in more favourable positions to play the ranking game.

Table 1: Categories of South African Universities*

\begin{tabular}{|c|c|c|}
\hline Category A & Category B & Category C \\
\hline $\begin{array}{c}\text { Top Research-intensive } \\
\text { universities }\end{array}$ & $\begin{array}{c}\text { Teaching and Research } \\
\text { universities }\end{array}$ & $\begin{array}{c}\text { Teaching universities } \\
\text { with limited research } \\
\text { (Universities of Technology) }\end{array}$ \\
\hline $\begin{array}{l}\text { - University of Cape Town } \\
\text { - University of the } \\
\text { Witwatersrand } \\
\text { - Stellenbosch University } \\
\text { - University of Pretoria } \\
\text { - University of KwaZulu-Natal }\end{array}$ & $\begin{array}{l}\text { - University of the Free State } \\
\text { - Rhodes University } \\
\text { - North-West University } \\
\text { - University of Fort Hare } \\
\text { - University of Limpopo } \\
\text { - University of the Western Cape } \\
\text { - University of Johannesburg } \\
\text { - Nelson Mandela University } \\
\text { - University of Zululand }\end{array}$ & $\begin{array}{l}\text { - Vaal University of Technology } \\
\text { - Central University of Technology } \\
\text { - Durban University of Technology } \\
\text { - Mangosuthu University of } \\
\text { Technology } \\
\text { - Tshwane University of Technology } \\
\text { - Cape Peninsula University of } \\
\text { - Uechnology } \\
\text { - University of Venda }\end{array}$ \\
\hline
\end{tabular}

* Recently established universities are not represented such as Sifako Makgatho Health Sciences University, Sol Plaatje University and the University of Mpumalanga.

Source: Adapted from Ntshoe and Selesho (2014)

In 2015/16 the THE ranking included 800 universities from 70 different countries of which 147 of the top universities were from the US. Within the top 10 highly ranked universities, the majority were from the US and the UK with only one from the European Union (EU) in ninth place. The 2015/2016 ranking thus marked the first year that a university outside the US or the UK was listed in the top ten for a decade. An analysis of the ARWU, THE and QS rankings in 2015/16 indicates that some South African universities have chosen to play the global ranking game and that certain institutional types are able to be ranked. Table 2 indicates that ten universities out of a total of 26 in South Africa are ranked in global ranking systems such as the ARWU, THE and QS. Of the ten ranked universities, four appear in ARWU, six in THE and nine in QS ranking systems. Two comprehensive universities are ranked, one (University of South Africa) in the THE and one (University of Johannesburg) in the QS. Notably, none of the universities of technology are ranked in the three ranking systems. The four universities that are ranked in the ARWU are all research-oriented universities (see Table 2). More South African research-oriented universities are ranked in the THE even though only one comprehensive university (University of South Africa) appears in the top 800 universities. Table 2 also indicates that 
a wider spread of universities is ranked in QS rankings which include all the researchintensive universities, three teaching and research universities but no universities of technology are ranked. Within the South African context, global ranking systems have the ability to perpetuate disadvantages at a systemic level in HE as well as within universities between core functions such as research, and teaching and learning.

The analysis of the South African universities that are able to compete in the three global rankings indicates that universities with a professional and vocational/teaching focus such as the universities of technology lag behind research-oriented universities in the three global ranking systems. Ntshoe and Selesho (2014) argue that historically disadvantaged universities and universities of technology have challenges playing the global ranking game because their focus is on teaching and meeting national priorities related to access and redress.

Table 2: Ranking of South African Universities in ARWU, THE and QS

\begin{tabular}{|c|c|c|c|c|c|}
\hline \multicolumn{2}{|c|}{ ARWU (2015) } & \multicolumn{2}{|c|}{ THE (2015/2016) } & \multicolumn{2}{|c|}{ QS (2015/2016) } \\
\hline Ranking & University & Ranking & University & Ranking & University \\
\hline $101-200$ & & 120 & $\begin{array}{l}\text { University of } \\
\text { Cape Town }\end{array}$ & $171(57.8)$ & $\begin{array}{l}\text { University of } \\
\text { Cape Town }\end{array}$ \\
\hline \multirow[t]{2}{*}{$201-300$} & $\begin{array}{l}\text { University of } \\
\text { Cape Town }\end{array}$ & \multirow[t]{2}{*}{$201-250$} & \multirow[t]{2}{*}{$\begin{array}{l}\text { University of the } \\
\text { Witwatersrand }\end{array}$} & & \\
\hline & $\begin{array}{l}\text { University of the } \\
\text { Witwatersrand }\end{array}$ & & & & \\
\hline \multirow[t]{2}{*}{$301-400$} & & \multirow[t]{2}{*}{$301-350$} & \multirow[t]{2}{*}{$\begin{array}{l}\text { Stellenbosch } \\
\text { University }\end{array}$} & 302 (42.3) & $\begin{array}{l}\text { Stellenbosch } \\
\text { University }\end{array}$ \\
\hline & & & & 331 (39.7) & $\begin{array}{l}\text { University of the } \\
\text { Witwatersrand }\end{array}$ \\
\hline \multirow[t]{2}{*}{$401-500$} & $\begin{array}{l}\text { University of } \\
\text { KwaZulu-Natal }\end{array}$ & \multirow[t]{2}{*}{$401-500$} & \multirow[t]{2}{*}{$\begin{array}{l}\text { University of } \\
\text { KwaZulu-Natal }\end{array}$} & & \\
\hline & $\begin{array}{l}\text { Stellenbosch } \\
\text { University }\end{array}$ & & & & \\
\hline \multirow[t]{3}{*}{$501-600$} & & \multirow[t]{3}{*}{$501-600$} & \multirow{3}{*}{$\begin{array}{l}\text { University of } \\
\text { Pretoria }\end{array}$} & \multirow[t]{3}{*}{$501-550$} & Rhodes University \\
\hline & & & & & $\begin{array}{l}\text { University of } \\
\text { Pretoria }\end{array}$ \\
\hline & & & & & $\begin{array}{l}\text { University of } \\
\text { KwaZulu-Natal }\end{array}$ \\
\hline \multirow[t]{3}{*}{$601-800$} & & \multirow[t]{3}{*}{$601-800$} & \multirow[t]{3}{*}{$\begin{array}{l}\text { University of } \\
\text { South Africa }\end{array}$} & $601-650$ & $\begin{array}{l}\text { University of } \\
\text { Johannesburg }\end{array}$ \\
\hline & & & & $701+$ & $\begin{array}{l}\text { North West } \\
\text { University }\end{array}$ \\
\hline & & & & $701+$ & $\begin{array}{l}\text { University of the } \\
\text { Western Cape }\end{array}$ \\
\hline
\end{tabular}

Source: ARWU, THE and QS websites (2016)

The uneven focus on research in the global rankings detracts from teaching and learning. The methodologies of the three ranking systems are also not appropriate within the South African context since only a few universities have the resources and research focus to play the global ranking game. The rankings also ignore national priorities such as the 
fees crisis, student success, the quality of teaching and learning (CHE, 2014) and support for national and regional goals. These quality improvement priorities are, however, not accounted for in the global ranking methodologies since the performance criteria in the rankings are biased towards research. Without the government's active pursuit of differentiation and a sincere commitment from individual universities to improve the quality of teaching and learning, teaching and learning will continue to retain its position as the Cinderella function in $\mathrm{HE}$ due to the focus on research in global rankings and the consequent pursuit of world-class university status as defined by global rankings.

South African HE is still confronted with challenges to meet national transformation imperatives. Shariffuddin et al. (2016) contend that transformation of HE is a matter of global concern even though the issues may vary depending on contextual realities in a country. Governments undertake transformation in HE in order to improve the provision of tertiary education in areas such as research, funding, differentiation, policy and quality (Shariffuddin et al., 2017). Shariffuddin et al. (2017) thus argue that this necessitates an understanding of the problems which confront academics as well as solutions which assist and motivate academics to achieve institutional goals within the context of transformation. However, Habib (2016) argues that the post-apartheid HE system experiences a lag compared to other developing countries with regard to competitiveness and performance.

The post-apartheid HE context is complex (Dlamini, 2016) and laden with challenges such as the increasing costs of $\mathrm{HE}$, the under-preparedness of students for $\mathrm{HE}$, epistemological access and low graduation rates (Dlamini, 2016; Habib, 2016). Dlamini (2016) argues that most HE institutions are not in a position to be research-intensive universities. Limited resources and competing priorities characterise HE in South Africa (Dlamini, 2016). Students are under-prepared, tuition fees are high and calls have been made for decolonisation and free HE. How best to finance HE is a consideration within the context of the financial burden on students. Solutions based on corporate models may worsen rather than alleviate the current student debt. Marketisation and commodification of HE have ushered in decisions which are impervious to the historical context in which South Africa finds itself (Dlamini, 2016). Ethical social change will not be achieved by policies which allow a few historically advantaged institutions to be the winners with the previously disadvantaged institutions emerging as the losers in the ranking game in South Africa. Considerations for the historical context of HE in South Africa should guide ethical decisions to play the ranking game with reflections on the consequences for teaching and learning, student fees, and decolonisation imperatives. Universities in Finland are not ranked, yet they produce quality education (Habib, 2016). Considerations of this nature should inform an identity for South African universities. Dlamini (2016) thus argues that South African universities should carve out their own identities within their context and the global arena.

Transformation of staff and students remains a concern for HE. The reality at some historically disadvantaged universities relates to student and staff protests as well as a managerial and financial crisis (Habib, 2016). The consequences of apartheid are still evident in HE today. Habib (2016:43) contends that South Africa does not currently have 
any university in the top 50 in any of the global rankings and argues that South Africa needs a HE system with universities that are differentiated "... each with different mandates and responsibilities, independent and yet connected to one another, thereby creating a seamless system that is both nationally responsive and globally competitive". The South African HE system bears the brunt of a racialised legacy (Habib, 2016). The historically advantaged universities are in the best position to produce more postgraduate students and to make the greatest contribution to high-level research (Habib, 2016). Despite this reality, Habib (2016) argues that historically disadvantaged universities in South Africa aspire to play the ranking game and to transform into research-intensive universities such as their historically advantaged counter parts. This impossibility in the short term has prevented the HE system from meeting societal needs according to Habib (2016). South African universities are also increasingly becoming corporatised (Habib, 2016). Shariffuddin et al. (2016) advocate for more research on different types of HE institutions as they respond to transformation in the Malaysian context. Such research would be valuable in the South African context as well, since Shariffuddin et al. (2016) acknowledge that different types of institutions have unique characteristics and challenges which they face in responding to transformation imperatives. Shariffuddin et al. (2016) implore governments and university leaders to consider the issues and challenges inherent in transforming HE with regard to planning, strategising and implementing changes. This could include decisions to play the ranking game.

Dlamini (2016) argues that world-class universities are espoused even though they present a limited picture of HE. South African universities have chosen to play the ranking game despite an awareness of the nature and subjectivity of the rankings (Dlamini, 2006). There is a growing international market for $\mathrm{HE}$ and as such corporates are exerting market forces on universities. Global rankings of institutions are but one example of corporates exerting market forces and influencing decisions to play the ranking game. South African universities have adopted corporate practices such as playing the ranking game (Dlamini, 2016). The unequal playing field that characterises the global ranking game for different types of universities in South Africa is also understood by those who have chosen to play the ranking game. Internationalisation has also been adopted by research-intensive universities in South Africa (Dlamini, 2016). The realities that confront South African universities have not detracted from efforts to be considered as worldclass universities. Dlamini (2016) thus argues that differentiation is a necessary but not a sufficient condition for achieving world-class status. Dlamini (2016:54) further argues that acceptance of global rankings in the South African context is destructive and that South Africa should develop "a social theory of African universities constructed in terms of local social and economic realities". Some South African universities, such as the University of the Witwatersrand, have expressed aspirations to be world-class universities (Dlamini, 2016; Habib, 2016), despite the uncertainty regarding whether rankings increase the quality of teaching and learning or whether rankings serve the dictates of commercialisation and marketisation of HE. These historical challenges all have consequences for playing the ranking game and should be considered for their impact on the South African HE system. 
While decisions are made to play the ranking game, ethical issues rarely inform these decisions. Giroux (2002) thus argues that the corporate culture does not include ethical considerations. Globalisation has driven the changing context in which both governments and universities operate when playing the global ranking game. Neveling, Malan and Yortt (2014) argue that globalisation has influenced ethical business decision-making which is shaped by both internal organisational and external societal factors. Are criteria for ranking universities based on ethical decision-making given the unequal nature of $\mathrm{HE}$ institutions in a global context? The limitation of globalisation as a driving force emerges when universities choose to play the global ranking game. In order to position themselves in the global arena, governments have made decisions, which mimic each other, even with respect to their HE systems. Although globalisation is understood as being beyond an institution's control (Altbach, 2010; Mohrman et al., 2008), universities have strategised to become more global with a presence in global ranking systems. Consequently, isomorphism in universities has become evident in missions and purposes (Maringe, 2010). Wealthy universities in the US and UK are highly ranked in the ARWU, THE and QS, whereas universities from poorer nations such as South Africa, are either lowly ranked or not ranked at all. The aspiration to become ranked as a 'world-class' university is becoming a global phenomenon (Enders, 2014). Policy makers also use global ranking systems to assess the position of universities relative to each other nationally and internationally (Enders, 2014).

Internationally and in the South African context, governments are increasingly turning towards rankings for policy-making (Buela-Casal et al., 2007). However, policy makers and university leaders' reactions to rankings may detract from mission differentiation and the improvement of teaching and learning (Enders, 2014). Due to the influence of rankings, governments should focus on the HE system to improve all HE institutions in a differentiated system and encourage mission and policy differentiation. Within the global context, decisions based on isomorphism are not a guarantee of success (Goglio, 2016) and national policy cannot be expected to triumph over the homogenising effects of global rankings. Rankings are based on data produced by universities and governments (Swail, 2011) and Rauhvargers (2014) therefore argue that the collection of national institutional data could lead to informed policy-making. Governments would thus be remiss to ignore the influence of popular global rankings and as decision-makers, governments need to be aware of the limitations and what global rankings offer and mean (Rauhvargers, 2013). This could serve as a basis for ethical decision-making when playing the ranking game.

The ARWU, THE and QS emphasise reputation and resource-based perspectives of excellence. If improving the quality of all institutions matters, then HE system-driven global rankings are required to assess comparable institutional quality (Hurtado \& Pryor, 2011). Universities that participate in the ranking game all play the same game in the global context and prospective students who have access to the internet have exposure to the same information. Considerations related to the quality of universities have thus enabled decision-making when choosing a university to be based on reputational position. While 
the importance of teaching is recognised in the three global rankings, the various proxies present a HE management challenge since they are not an adequate measure and do not provide an indication of teaching quality; neither do they measure learning. According to Altbach (2012), measures for teaching quality are not debated widely at a national or global level and as such alternative measures for teaching quality have not made a mark on global rankings. As market leaders, global rankings have the potential to set new trends in rankings and HE policies that focus on teaching and learning as essential functions worthy of being placed on par with research rather than being rendered the Cinderella function in $\mathrm{HE}$.

In a move towards more ethical decision-making in playing the ranking game, valid rankings that are sensitive to context and that measure learning would be preferable. Process measures based on research generated through the scholarship of teaching and learning, which are linked to student learning and to relevant student output measures, are also required. In order to be applicable to $\mathrm{HE}$, enhancements to the ARWU, THE and QS with more diverse indicators are needed with a direct focus on teaching and learning. Ethical decision-making should guide decisions regarding whether a university should be ranked. In addition, the importance accorded to global rankings should not be considered for a few universities but for the value they add to the entire HE system. The value-add to HE in terms of teaching and learning needs to be factored into global rankings. In consultation with universities, governments should devise national policies to assess the quality of teaching through standards for excellent teaching which could serve as best practice and be incorporated as performance criteria in global rankings. Democratic considerations could also inform decisions to play the ranking game.

Higher education in South Africa operates in a democratic context. However, democracy has been sidelined in favour of the market-based neoliberal paradigm (Giroux, 2009). Higher education as a public good is increasingly giving way to corporate and market forces where managerial modes of governance guide decisions in universities (Giroux, 2009). This undermines the paramount need for ethical decision-making when deciding to play the global ranking game and is the case in the South African context as well. A university is the "protector and promoter of democratic values" (Giroux, 2009:672). The functions of teaching, learning and research are fundamental to HE and should spearhead knowledge and skills development (Dlamini, 2016). However, universities are no longer valued for their teaching and research but for their prestige as world-class universities and their value within the market (Giroux, 2009).

Giroux (2002) views universities as serving the public good and argues that ethical norms and democratic values should be valued in the role that a university plays in society. However, democratic values are being subsumed by commercial values according to (Giroux, 2002). Higher education in South Africa should thus be critical of global rankings due to historical realities which persist to this day. Monzó (2014) argues that democracy allows free citizens to collectively change society. In addition, Monzó (2014) advocates diverse epistemes to legitimise knowledge and argues that democracy employs an ethics that stresses humanity and frowns upon competition. Meeting national decolonisation 
imperatives should inform decisions in South African universities to play the ranking game. Monzó (2014) argues that inequality should be challenged in society to enable greater participation and inclusion. This is particularly apt in the South African context. Ethical decisions to play the ranking game should foreground the context of a university and its resources and form the basis of decisions to be ranked globally. Universities should be valued for their missions and contributions to advancing society (Monzó, 2014) and not for their value as a commodity. Giroux (2009) thus argues that teaching should be linked to achieving social issues. Global ranking systems could thus demonstrate HE's value to society through a more inclusive, democratic agenda which incorporates teaching and learning in their performance criteria. In the South African context, teaching and learning should be valued for its contribution to student success and improving throughput. Policy makers should thus be critical of assumptions and the appropriateness of global rankings within the South African differentiated HE system.

\section{Concluding remarks}

Global university ranking systems have blossomed in the last decade. The ranking criteria used in the ARWU, THE and QS global ranking systems are problematic since they are not contextualised and do not communicate much about teaching and learning or the quality of teaching and learning. The focus on research in the ranking criteria also detracts from teaching and learning and may mask problems in teaching and learning. Where criteria for teaching and learning are articulated in the ARWU, THE and QS, they focus on arbitrary proxies that are not widely accepted as indicators of quality.

South Africa's historical background presents challenges to playing the global ranking game since historically disadvantaged universities are not on par with historically advantaged universities. Global ranking systems have the ability to perpetuate disadvantages at a systemic level in HE in South Africa as well as within universities between core functions such as research, and teaching and learning. Despite not being highly ranked in global ranking systems, some South African universities are pursuing a global presence which may be to the detriment of national priorities such as the call for decolonisation of institutions and the curriculum, the student fee crisis, considerations of free HE, student success and improving teaching and learning. Playing the global ranking game in South Africa is further complicated due to the historical political situation which perpetuated inequalities in the HE system that remain to this day. Previous inequalities are played out in the ranking game where some universities have the resources to be ranked while others lag behind and still others choose not to play the global ranking game. Instead of perpetuating teaching and learning as the Cinderella function in HE, global ranking systems should be based on ethical decision-making and be flexible enough to allow their performance criteria to reflect holistic institutional performance of all the core functions of a university. The next generation of global ranking criteria would thus benefit from a more inclusive, democratic, nuanced and detailed focus on teaching and learning. 


\section{Acknowledgements}

I would like to express my gratitude to Professors Rajani Naidoo and Robin Shields for comments on an earlier draft.

\section{References}

Altbach, P.G., Reisberg, L. \& Rumbley, L.E. (2009). Trends in Global Higher education: Tracking an academic revolution. A report prepared for the UNESCO 2009 World Conference on Higher Education. United Nations Educational, Scientific and Cultural Organisation, Paris.

Altbach, P.G. (2010). Globalisation and the university: Myths and realities in an unequal world. Tertiary Education and Management, 10(1):3-25. https://doi.org/10.1080/13583883.2004.9967114

Altbach, P.G. (2012). The Globalization of College and University Rankings, Change, January/February:26-31. https://doi.org/10.1080/00091383.2012.636001

Amaral, A. (2014). Where are quality frontiers moving to? In: M. Joao Rosa \& A. Amaral (eds.), Quality Assurance in higher education: Contemporary debates. Springer. https://doi.org/10.1057/9781137374639_2

Badat, S. (2010a). Global rankings of universities: A perverse and present burden. In: E. Unterhalter \& V. Carpentier, 2010. Whose interests are we serving? Global inequalities and higher education. Basingstoke: Palgrave Macmillan. https://doi.org/10.1007/978-0-230-36507-0_5

Badat, S. (2010b). The challenges of transformation in higher education and training institutions in South Africa: Paper commissioned by the Development Bank of Southern Africa. April.

Biggs, J. \& Tang, C. (2011). Teaching for quality learning at university. 4th ed. England: Society for research into higher education and Open University Press.

Buela-Casal, G., Gutierrez-Martinex, O., Bermudex-Sanchez, M.P. \& Vadilio-Munoz, O. (2007). Comparative study of international academic rankings of universities. Scientometrics, 71(3):349-365. https://doi. org/10.1007/s11192-007-1653-8

Cloete, N. (2014). The South African higher education system: performance and policy. Studies in Higher Education, 39(8):1355-1368. https://doi.org/10.1080/03075079.2014.949533

Council on Higher Education (CHE). (2014). Framework for institutional quality enhancement in the second period of quality assurance: Quality Enhancement Project. Pretoria, South Africa: Council on Higher Education.

Department of Education (DoE). (1997). White Paper 3: A programme for Higher Education Transformation. Pretoria, South Africa: Department of Higher Education and Training.

Department of Higher Education and Training (DHET). (2013). White paper on building an expanded, effective and integrated post-school system. Pretoria, South Africa: Department of Higher Education and Training.

Department of Higher Education and Training (DHET). (2014). Policy framework on differentiation in the South African post-school system. Pretoria, South Africa: Department of Higher Education and Training.

Dill, D.D. (2005a). Convergence and Diversity: The role and influence of university rankings. Background paper. Public Policy for Academic Quality. The University of North Carolina at Chapel Hill, Department of Public Policy. 1-21. http://www.unc.edu/ppaq [Accessed 4 March 2016].

Dill, D.D. \& Soo, M. (2005b). Academic Quality, League Tables and Public Policy: A Cross-National Analysis of University Ranking Systems. Higher Education, 49(4):495-533. http://www.jstor.org/stable/25068082 [Accessed 4 March 2016]. https://doi.org/10.1007/s10734-004-1746-8

Dlamini, R. (2016). The global ranking tournament: A dialectic analysis of higher education in South Africa. South African Journal of Higher Education, 30(2):53-72. https://doi.org/10.20853/30-2-567

DiMaggio, P.J. \& Powell, W. (1983). The iron cage revisited: Institutional isomorphism and collective rationality in organizational fields. American Sociological Review, 48(2):147-160. https://doi.org/10.2307/2095101 
Enders, J. (2014). The Academic Arms Race: International Rankings and Global Competition for WorldClass Universities. In: A.W. Pettigrew, E Cornuel \& U. Hommel (eds.). The Institutional Development of Business Schools. Oxford: Oxford University Press. 155-175. https://doi.org/10.1093/acprof:o so/9780198713364.003.0007

Giroux, H. (2002). Neoliberalism, corporate culture, and the promise of higher education: The university as a democratic public sphere. Harvard Educational Review, 72(4):425-464. https://doi.org/10.17763/ haer.72.4.0515nr62324n71p1

Giroux, H.A. (2009). Democracy's nemesis: The rise of the corporate university. Cultural Studies $\leftrightarrow$ Critical Methodologies, 9(5):669-695.

Goglio, V. (2016). One size fits all? A different perspective on university rankings. Journal of Higher Education Policy and Management, 38(2):212-226. https://doi.org/10.1080/1360080X.2016.1150553

Gonzales, L.D. \& Nunez, A. (2014). The ranking regime and the production of knowledge: implications for Academia. The future of education research journals, education policy Analysis Archives, 22(31):1-19.

Habib, A. (2016). Transcending the past and reimagining the future of the South African university. Journal of Southern African Studies, 42(1):35-48. https://doi.org/10.1080/03057070.2016.1121716

Handel, D.D. \& Stolz, I. (2008). A comparative analysis of higher education ranking systems in Europe. Tertiary Education Management, 14(3):173-189. https://doi.org/10.1080/13583880802228158

Hazelkorn, E. (2014). Rankings and the global reputation race. New Directions for Higher Education, 168(winter):13-26.

Institute for Higher Education Policy (IHEP). (2009). Impact of college rankings on institutional decision making: Four country case studies. Issue brief, May.

Lindsay, T.K. (2013). The likelihood of higher education reform symposium: Higher Education and the Challenges of Reform. Society, 50:236-244. https://doi.org/10.1007/s12115-013-9649-x

Marginson, S. (2007a). University mission and identity for a post post-public era. Higher Education Research \& Development, 2(1):117-131. https://doi.org/10.1080/07294360601166851

Marginson, S. (2007b). Global University Rankings: Implications in general and for Australia. Journal of Higher Education Policy and Management, 29(2):131-142. https://doi.org/10.1080/13600800701351660

Marginson, S. (2007c). Global University rankings: where to from here? Asia-Pacific Association for international education. National University of Singapore, 7-9 March.

Marginson, S. (2008). Globalization, national development and university rankings. Conference proceedings, International Symposium on University ranking: Global trends and comparative perspectives, VNU headquarters, Hanoi, Vietnam, 12-13 November.

Marginson, S. (2016). Global university ranking and performance improvement. What kind of international academic relations are created by rankings? Proceedings of the IREG-8 Conference, University rankings and international academic relations - A bridging tool or a hindrance? Session 1: The impact of rankings on internationalisation, Lisbon, 4-6 May.

Marginson, S. \& Van der Wende, M. (2006). To rank or to be ranked: The impact of global rankings in higher education. Journal of Studies in International Education, 11(3-4):306-329. https://doi. org/10.1177/1028315307303544

Maringe, F. (2010). The meaning of globalization and internationalization in HE: Findings from a world survey. In: F. Maringe \& N. Foskett, (eds.). Globalization and Internationalization in Higher Education: Theoretical, Strategic and Management Perspectives. Bloomsbury Academic. 17-34.

Martins, L.L. (2005). A model of the effects of reputational rankings on organizational change. Organization Science, 16(6):701-720. https://doi.org/10.1287/orsc.1050.0144

Monzó, L.D. (2014). A Critical Pedagogy for Democracy: Confronting Higher Education's Neoliberal Agenda with a Critical Latina Feminist Episteme. Journal for Critical Education Policy Studies (JCEPS), 12(1):73-100.

Neveling, A., Malan, D. \& Yortt, A. (2014). Globalisation and its influence on ethical decision-making in business: China and intellectual property. African Journal of Business Ethics, 8(1):45-67. https://doi. org/10.15249/8-1-17 
Ntshoe, I.M. \& Selesho, J.M. (2014). Institutional ranking in a differentiated higher education in South Africa. SAJHE, 28(4):1554-1574.

O'Connell, C. (2015). An examination of global university rankings as a new mechanism influencing mission differentiation: the UK context. Tertiary Education and Management, 21(2):111-126. https://doi.org/10.108 0/13583883.2015.1017832

Peters, K. (2007). Business school rankings: content and context. Journal of Management Development, 26(1):49-53. https://doi.org/10.1108/02621710710720086

Pinheiro, R. (2013). Bridging the local with the global: Building a new university on the fringes of Europe. Tertiary Education and Management, 19(2):144-160. https://doi.org/10.1080/13583883.2013.782063

Quacqarelli-Symonds Rankings Website. (2016). QS World University Rankings 2015/16. https://www. topuniversities.com/university-rankings [Accessed 29 March 2016].

Rauhvargers, A. (2013). Global University Rankings and their impact - Report II. European University Association. EUA Report on Rankings 2013. Brussels, Belgium: European University Association.

Rossi, F. (2010). Massification, competition and organizational diversity in higher education: evidence from Italy. Studies in Higher Education, 35(3):277-300. https://doi.org/10.1080/03075070903050539

Shariffuddin, S.A., Razali, J.R. \& Ghani, M.A. (2017). A review on higher education institutions transformation in selected regions. Proceedings of International Conference on Humanities, Language, Culture \& Business, Penang. 2:75-84.

Shariffuddin, S.A., Razali, J.R., Ghani, M.A., Shaaidi, W.R. \& Ibrahim, I.S.A. (2016). Transformation of higher education institutions in Malaysia: a review. Journal of Global Business and Social Entrepreneurship, 1(2):126-136.

Soh, K. (2017). The seven deadly sins of world university ranking: a summary from seven papers. Journal of Higher Education Policy and Management, 39(1):104-115. https://doi.org/10.1080/1360080X.2016.1254431

THE (Times Higher Education) Website. (2016). World University Rankings. https://www.timeshighereducation. com/world-university-rankings [Accessed 29 March 2016].

Van Vught, F. (2008). Mission diversity and reputation in higher education. Higher Education Policy, 21(2):151-174. https://doi.org/10.1057/hep.2008.5 